\title{
RESOURCE SELECTION BY HILL SHEEP: DIRECT FLOCK OBSERVATIONS VERSUS GPS TRACKING
}

\author{
WILLIAMS, B. ${ }^{1,2} *$ - WALSH, M. ${ }^{1}$ - GORMALLY, M. ${ }^{2}-$ WALLS, S. ${ }^{3}-$ SHEAHAN, J. ${ }^{4}$ \\ ${ }^{I}$ Teagasc Research Centre \\ Mellows Campus, Athenry, Co. Galway, Ireland \\ (phone: +353-91-845846; fax: +353-91-845847) \\ ${ }^{2}$ Applied Ecology Unit, Centre for Environmental Science \\ National University of Ireland, Galway \\ University Road, Galway, Ireland \\ (phone: +353-91-492294; fax: +353-91-494598) \\ ${ }^{3}$ Anatrack Ltd \\ 52 Furzebrook Road, Wareham, Dorset, BH20 5AX, UK \\ ${ }^{4}$ Department of Mathematics \\ National University of Ireland, Galway \\ University Road, Galway, Ireland \\ *Corresponding author \\ e-mail:bryony.williams@gmail.com \\ (Received 24 ${ }^{\text {th }}$ March 2010 ; accepted $10^{\text {th }}$ September 2010)
}

\begin{abstract}
Uplands and peatlands are of international ecological importance and heavy grazing pressure has been implicated in a decline in their condition. Therefore, a better understanding of grazer behaviour could aid the design of conservation strategies. The objective of this study was to test whether the same resource selection results were obtained from direct flock observations as simultaneously-run GPS tracking studies. Direct flock observations were conducted on 50 sampling days, June 2004-July 2005. Habitat, habitat condition and grazing lawn frequency maps were produced. Resource use and availability were estimated using range analysis and GIS, and resource selection was analysed using weighted compositional analysis. Flock distribution was uneven with a mean of 0.0-8.9 sheep/ha observed based on a 1 ha grid system. Habitat selection based on direct observations varied seasonally with acid grasslandrelated habitats selected most in spring, summer and autumn, and wet heath and blanket bog selected most in winter. Moderately damaged areas and grid squares containing numerous/extensive grazing lawns were consistently selected most $(P<0.05)$. Resource selection findings based on direct flock observations were consistent with those obtained using detailed GPS tracking data from fewer individuals. Resource management recommendations are discussed.
\end{abstract}

Keywords: agriculture; ecology; environment; resource management; resource selection

\section{Introduction}

Uplands and peatlands are of international importance for their associated flora and fauna and restricted global distribution and extent. Associated habitats, such as 'temperate Atlantic wet heath with Erica ciliaris and Erica tetralix' and active 'blanket bog', are recognised as priority habitats for conservation at a European level (European Commission, 2008). Heather-dominated landscapes are reported to be best represented in the British Isles (Thompson et al., 1995b), which also supports 18-22\% of the world's blanket bog (Cadbury, 1987, Department of Arts Heritage Gaeltacht and the Islands, 2002). However, grazing-related damage to European uplands is most notable 
in the UK and Ireland (European Environmental Advisory Councils, 1999) where sheep farming is the prevalent land use. This damage is probably attributable to relatively high sheep numbers; of nearly 26 million breeding sheep in northern Europe, $80 \%$ are on the British Isles (Dýrmundsson, 2006).

EU policy has a large influence on the management of areas with poor soil and climatic conditions for agricultural production, such as upland areas. Irish sheep farmers (mainly hill sheep farmers, L. Connolly pers. comm.) are highly dependent on direct payments and additional subsidies, for example, excluding subsidies, production costs exceeded incomes generated in 2006 (Connolly et al., 2007). EU policy in recent decades encouraged high stock numbers which resulted in grazing-related damage (Gillmor and Walsh, 1993), conversely, there is now increasing concern that changes in financial support will lead to undergrazing and land abandonment in European uplands (Moravec and Zemeckis, 2007). Grazing animals are widely recognised as an important management tool in ecological conservation (Rowell and Clarke, 1988, Thompson et al., 1995a) and agri-environment schemes provide support to hill farmers that is essential if grazers are to be kept on upland areas. A better understanding of grazer behaviour could increase the efficacy of agri-environment schemes.

Provenza and Cincotta (1993) recognised the difficulty in predicting foraging behaviour. A complex computer-based hill grazing management model of sheep stocking regime impacts on hill vegetation has been developed (Armstrong et al., 1997a; Armstrong et al., 1997b). This model has been used by various organisations to aid decision-making (Hester and Baillie, 1998) and a new version of this model, which incorporates additional components, is awaiting further data for validation before release (HillPlan; Macaulay Institute, 2009).

Grazer preferences have been investigated using analysis of faecal, stomach and oesophageal samples (Heady, 1964; Williams, 1969; McInnis et al., 1983). Seasonal diet selection of hill sheep has been reported in several studies (Welch, 1984; Bullock, 1985; Grant et al.; 1985, Grant et al., 1987). Vibracorders, sensors built into GPS collars and video recordings have been used to investigate sheep behaviour including activity, circadian rhythm and inter-animal distances (Hulbert et al., 1998; Iason et al., 1999; Sibbald et al., 2000; Umstätter et al., 2008). Direct observations of hill sheep behaviour activity, location and orientation have also been made (Hunter, 1962; Berggren-Thomas and Hohenboken, 1986; Clarke et al., 1995; Hester et al., 1999).

Scottish Blackface is the dominant hill sheep breed in the British Isles and, therefore, the obvious choice as the study animal. Informative studies of habitat selection by hill sheep have previously been based on direct observation data at the very detailed plant community level (Hunter, 1962) or within 2.5 ha plots and with only two habitats available (Clarke et al., 1995). The former has practical limitations for large-scale repeatability and the latter excludes a number of habitats typically available on heterogeneous hill areas.

Key findings from studies by the same authors, which used GPS tracking collars on hill sheep with access to a mosaic of upland and peatland habitats, are that sheep; (i) occupied only $9-20 \%$ of the area available to them, (ii) selected acid grassland most and avoided blanket bog, (iii) mostly selected 1 ha grid squares that contained numerous/extensive grazing lawns (patches of grassland with short, dense swards that have been heavily grazed (McNaughton, 1984) and (iv) did not avoid severely damaged areas with comparatively low forage availability (Williams, 2008; Williams et al., 2009). 
The objectives of this study are (i) to investigate resource selection based on direct flock observations and (ii) to compare these results (that have a relatively large sample size) with findings from GPS tracking collars on a limited number of sheep (Williams, 2008; Williams et al., 2009) which were made at the same time. The implications for conservation strategies using the two methods are also discussed.

\section{Methods}

\section{Study area}

The study area consisted of 216.9 ha of upland and peatland at the Teagasc Hill Sheep Farm in Co. Mayo, Ireland (53 $\left.37^{\prime} \mathrm{N}, 09^{\circ} 41^{\prime} \mathrm{W}\right)$. The dominant habitats were blanket bog and wet heath, with fragmented patches of acid grassland. The study area was within the catchment area of the Erriff River and part of the Mweelrea/Sheeffry/Erriff Complex candidate Special Area for Conservation and proposed Natural Heritage Area. The general aspect was south-southeasterly and the altitude ranged from 15-275 $\mathrm{m}$ OD, with the highest, steepest slopes in the northwest corner of the study area. The site was Class 5 for agricultural land use (Gardiner and Radford, 1980). Soils were mainly peats and peat depths ranged between 30 and $525 \mathrm{~cm}$ (Walsh et al., 2000).

A maritime temperate climate prevailed with the nearest synoptic meteorological station located in Belmullet, Co. Mayo, approximately $70 \mathrm{~km}$ distant. Based on the most recent 30-year averages (1961-1990) recorded at Belmullet, the mean daily temperature was $14.0^{\circ} \mathrm{C}$ in July and $5.7^{\circ} \mathrm{C}$ in January, and the annual mean daily duration of bright sunshine was $3.5 \mathrm{~h}$ (Met Éireann, undated). The mean annual rainfall recorded on-site (1993-2005) was $2086.4 \mathrm{~mm}$ (L. O'Malley pers. comm.). The minimum and maximum hours of daylight at the study area were calculated as $7 \mathrm{~h} 27 \mathrm{~min}$ and $17 \mathrm{~h} 4 \mathrm{~min}$.

Scottish Blackface sheep grazed the study area at stocking rates of 0.4 ewes/ha in spring (March-May), 0.9 ewes/ha in summer (June-August) and autumn (SeptemberNovember) and 0.8 ewes/ha in winter (December-February). These calculations were based on 2004-2005 averages, omitted lambs and included hoggets at a ratio of 3 hoggets: 2 ewes. The study area was grazed for 348 days in 2004 and 351 days in 2005. Supplementary feed was not given in the study area. Ewes lambed in early April with a productivity of 1.0 lamb/ewe (based on mean data 2004-2006). Approximately 80 females were retained annually as replacements. (L. O'Malley pers. comm.). Sheep had open access across the site, which was marked with pegs in a $100 \times 100 \mathrm{~m}$ (1 ha) grid.

\section{Direct flock observations}

Sheep locations and behaviour activities were recorded for individuals at the time of sighting. Locations were estimated to the nearest grid square and behaviour activity categories used followed those of (Hester et al., 1999), i.e. grazing, moving, standing, lying, interacting and other ('other' activities included defecating, scratching against a post and the shaking of rain water from fleeces).

Flock observations were made from along a set route, approximately $8.2 \mathrm{~km}$ in length, designed (i) to minimise disturbance to sheep before recording locations and behaviour activities and (ii) to gain sight over most of the study area. Flock observations began at 10:00 local time and took approximately 5 hours to complete. Recordings were made in all weather conditions using a Dictaphone sealed in a ziplock plastic bag and 
transcribed to an Excel spreadsheet. Flock observations were conducted twice weekly for five weeks for each of five seasonal sampling periods between June 2004 and July 2005 , providing a total of 50 sampling days.

\section{Habitat, habitat condition and grazing lawn frequency surveys}

Habitats were mapped using the UK and Irish classifications and guidelines (Nature Conservancy Council, 1990; Fossitt, 2000; Heritage Council, 2002) to enable comparison with other studies, increased replicability and further applications. Habitat patches $\geq 0.25$ ha were mapped with the aid of colour, ortho-corrected aerial photographs taken in 2000 (Ordnance Survey Ireland, Dublin, Ireland). Habitats are referred to throughout by the Irish classification names, the UK equivalents are detailed in Williams (2008).

Habitat condition of the study area was originally mapped in (Bleasdale and Heffron, 1999) and ground-truthed for change in 2005. Assessment was made following the method described by Dúchas the Heritage Service and the Department of Agriculture and Food (1999) which uses six condition categories; undamaged, moderateundamaged, moderately damaged, moderately-severely damaged, severely damaged and very severely damaged. Habitat condition indicators include (but are not exclusive to) grazing-related damage, are defined for each habitat type, and include vegetation cover and growth, particularly the cover and condition of Calluna vulgaris (L.) Huds and the cover of Nardus stricta (L.), species richness, sward height, exposed soil and evidence of burning.

All acid grassland patches were grazing lawns, a product of intensive grazing, but acid grassland patches were under-represented on the habitat map because patches were fragmented and often too small to map following mapping guidelines. To efficiently obtain more information on acid grassland distribution, grazing lawn frequency by grid square was mapped. Grazing lawn frequencies were allocated for each full or part $100 \times 100 \mathrm{~m}$ grid square in 2005 . Categories of grazing lawn patches $\left(\sim 4-7 \mathrm{~m}^{2}\right.$ or the equivalent area) were (i) none, (ii) few (1-5 patches), (iii) several (6-10) and (iv) numerous/extensive $(>10)$. In the instance of a part grid square, on the boundary of the study area, it was classified as numerous/extensive if acid grassland occupied $\geq 0.3$ of its area.

The habitat, habitat condition and grazing lawn frequency maps were digitised using Geographical Information System (GIS) software (ArcGIS Desktop, V.9.1 \& 8.3, ESRI, Redlands, CA, USA).

\section{Data analysis}

\section{Resource analysis}

The habitat, habitat condition and grazing lawn frequency maps were imported into range analysis software (Ranges7, Anatrack Ltd, Dorset, UK) and analyses performed to estimate resource content of the study area. Availability and flock use of these resources based on grid squares was estimated using ArcGIS (including the identity tool) and Excel (including pivot tables). 


\section{Statistical analysis}

During the daily 5 hour direct flock observations, visibility conditions (high or low) were recorded. Spearman's rank correlation test (implemented using SPSS v.15, Chicago, Illinois, USA www.spss.com) was used to test whether there was a correlation between visibility conditions and the proportion of the flock sighted.

Selection of habitat, habitat condition and grazing lawn frequency categories was examined using weighted compositional analysis (Compos Analysis V.6.2+, Smith Ecology Ltd, Abergavenny, UK). Each sampling day was weighted by the number of observations. Proportions of resource use were compared with those available, using Wilks' lambda $(\Lambda)$ test (MANOVA). (Aebischer et al., 1993) used a two-step approach based on Johnson's selection levels (Johnson, 1980), which was previously implemented with the GPS data, comparing (i) habitats available within the study area with those used within ewe ranges (broad level) and (ii) habitats available within ewe ranges compared with those used at location (detailed level), (Williams, 2008). This method was repeated with GPS data for habitat condition and grazing lawn frequency (Williams et al., 2009). However, with the flock observation data, only a one-step approach could be used, comparing resources available within the study area with those used at the 1 ha grid square level. This estimate is intermediate between the broad and detailed levels because there is no precise location data and most individuals were unmarked prohibiting ewe range estimates.

Compositional analysis tests are based on percentage values, which overcame the potential problem arising from the inclusion of part and complete grid squares. Resource use and available percentage data will not have an exact multivariate normal distribution, and hence randomisation tests were used to evaluate the significance of $\Lambda$ and t values (Aebischer et al., 1993).

All sampling days were combined for annual tests, with summer resource use and number of observation values averaged because this season was duplicated. To enable comparison with results previously obtained from a limited number of sheep tracked using GPS simultaneous to these direct flock observations, tests were repeated using three habitat and three habitat condition groups (Table la,c). Where the two combination habitats (characteristics of two habitats were exhibited in these instances, i.e. blanket bog-acid grassland and wet heath-acid grassland) overlapped two habitat groups, values were divided equally between the two corresponding habitat groups.

A total of 8791 sheep observations were made over the 50 sampling days. All were suitable for analysis of sheep behaviour activities and proportions of the flock sighted. Sixty-five observations were omitted from compositional analyses as these were of sheep that chose to occupy a fenced exclosure outside the study area and were unsuitable for resource selection analysis because different management practices in the exclosure affected classification of habitats, habitat condition and grazing lawn frequency. 
Table 1. Availability of habitats, grid squares containing different frequencies of grazing lawns and areas of differing habitat condition in the 216.9 ha study area

\begin{tabular}{llll}
\hline Category & $\begin{array}{l}\text { Abbreviated } \\
\text { name/code }\end{array}$ & $\begin{array}{l}\text { Area } \\
(\boldsymbol{\%})\end{array}$ & Group \\
\hline a) Habitat & Blanket bog & 52.8 & Bog \\
Blanket bog & Wet heath & 35.3 & Heath \\
Wet heath & Acid grassland & 3.0 & Grassland \\
Semi-natural dry-humid acid grassland & Heath-grassland & 2.4 & Heath \& grassland \\
Wet heath-Semi-natural dry-humid acid gsld & Cutover bog & 2.0 & Bog \\
Cutover bog & Bracken & 1.6 & Grassland \\
Dense bracken & Bog-grassland & 1.6 & Bog \& grassland \\
Blanket bog-Semi-natural dry-humid acid gsld & Eroding bog & 0.5 & Bog \\
Eroding blanket bog & Wet grassland & 0.5 & Grassland \\
Semi-natural wet grassland & Track & 0.4 & Grassland \\
Buildings and artificial surfaces & Earth banks & 0.1 & Grassland \\
Earth banks & & & \\
\hline b) Grazing lawn frequency & None & 11.4 & N/A \\
None & Few & 36.8 & N/A \\
Few (0-5) & Several & 17.4 & N/A \\
Several (6-10 or equivalent) & Numerous & 34.3 & N/A \\
Numerous ( $\geq 10)$ /extensive & & & \\
\hline c) Habitat condition & $\mathrm{U}$ & 29.5 & Undamaged (U) \\
Undamaged areas & MU & 22.3 & Moderately damaged (M) \\
Moderate-undamaged areas & M & 21.0 & Moderately damaged (M) \\
Moderately damaged areas & MS & 5.5 & Moderately damaged (M) \\
Moderate-severely damaged areas & S & 2.0 & Severely damaged (S) \\
Severely damaged areas & VS & 19.8 & Severely damaged (S) \\
Very severely damaged areas & & & \\
\hline
\end{tabular}

\section{Results}

\section{Direct flock observations}

A mean of $79.1 \%$ (min. $57.6 \%$, max. $94.6 \%$ ) of the flock was sighted on 50 sampling days. The Spearman rank test indicated that the proportion of the flock sighted was not affected by visibility conditions (correlation coefficient $=0.168, P=0.245, \mathrm{n}=50$ ).

Grazing was the main behaviour activity observed with means of 63.1-94.6\% of sightings per sampling period (Fig. 1). Lying was the second-most observed activity with means of 2.5-30.2\% of sightings per sampling period. Proportions of sheep sighted grazing were highest in winter. The highest proportions of sheep sighted lying were in both summers and autumn. The number of observations was low in spring because ewes were taken off the study area and given supplementary feed prelambing if twin-bearing or of low body condition. 


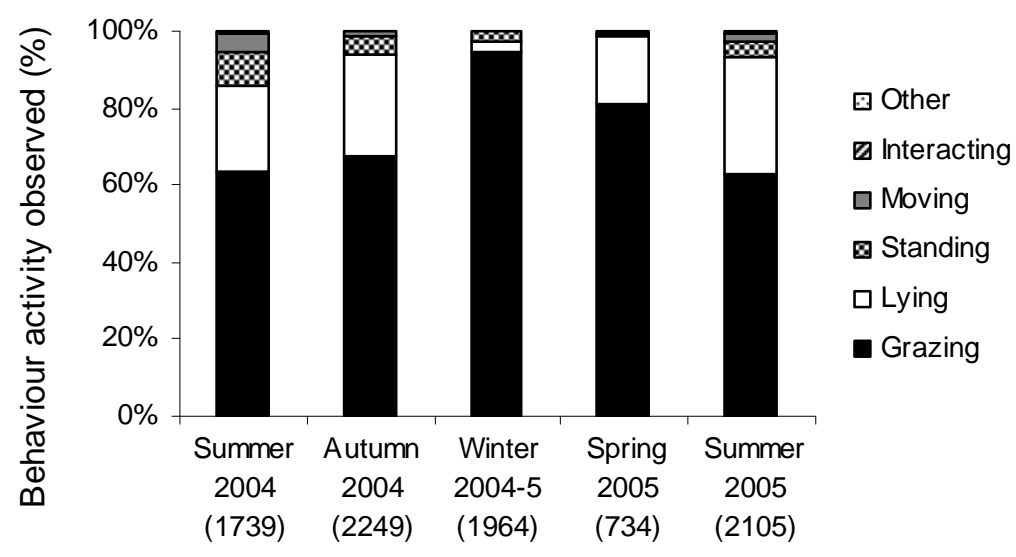

Sampling period

Figure 1. Mean proportions of behaviour activities of Scottish Blackface hill sheep observed on 10 days for each of five seasonal sampling periods. The total number of sheep observations made in each sampling period is included in x-axis labels

Flock distribution across the study area was clearly uneven (Fig. 2). Five categories, with four manual breaks in sheep density values, were used to identify (i) unoccupied grid squares (0.00), (ii) squares occupied at or below densities expected based on the annual stocking rate of 0.74-0.75 ewes/ha (L. O'Malley pers. comm.), (iii) squares occupied at densities greater than expected based on the annual stocking rate $(>0.75$, subdivided into two categories using the mean midpoint between 0.75 and the highest mean observed density). Sheep densities were lower overall in spring as most of the flock was brought in for supplementary feed prelambing. Sheep densities were higher overall in summer as sheep numbers observed included hoggets and lambs whereas annual stocking rate calculations excluded lambs and included hoggets as ewes at a 3:2 ratio (L. O'Malley pers. comm.). A preference for the northwest quarter of the study area was most marked in summer (2004 and 2005) compared with alternative seasons. Between season and year variation was evident in flock distribution, although distribution was most similar for the two consecutive summers sampled.

The mean sheep density by grid square across all 50 sampling days indicated a preference for the northwest quarter and northeast corner of the study area (Fig. 3a). Mean densities per sampling period and overall are presented in Figures 2 and $3 a$ but absolute sheep densities by grid square for the 50 sampling days found observed densities ranged between 0.00 and 158.13 sheep/ha with a mean density of 0.93 sheep/ha. However, the highest observed sheep density for each sampling period was consistently found in part grid squares on the boundary of the study area ranging in size between 0.05 and 0.13 ha. The highest number of sheep seen in a grid square at any one time was 23 and this occurred in complete, 1 ha grid squares on two occasions (i.e. a density of 23.00 sheep/ha).

On any one sampling day, sheep were observed to be dispersed across the study area, as opposed to being congregated in one group. Frequency histograms indicated that typically the majority of grid squares were unoccupied, none were occupied at low densities between 0.01 and 0.93 sheep/ha, and sheep occupation was at densities of $\geq 0.94$ sheep/ha (Fig. 4). 

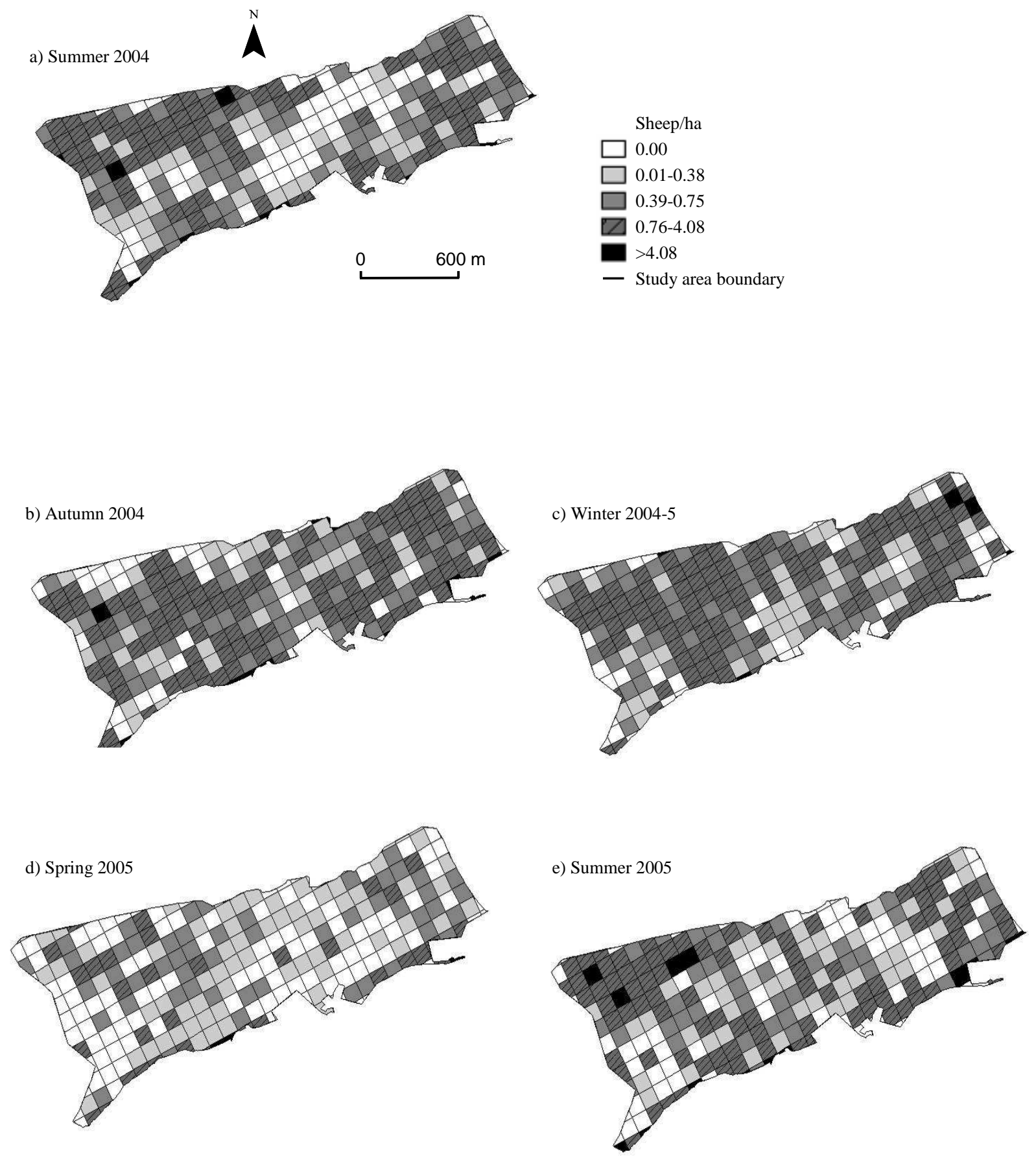

Figure 2. Mean sheep density by grid square from 10 days for each of five seasonal sampling period 
a) Mean sheep density (all 50 sampling days)
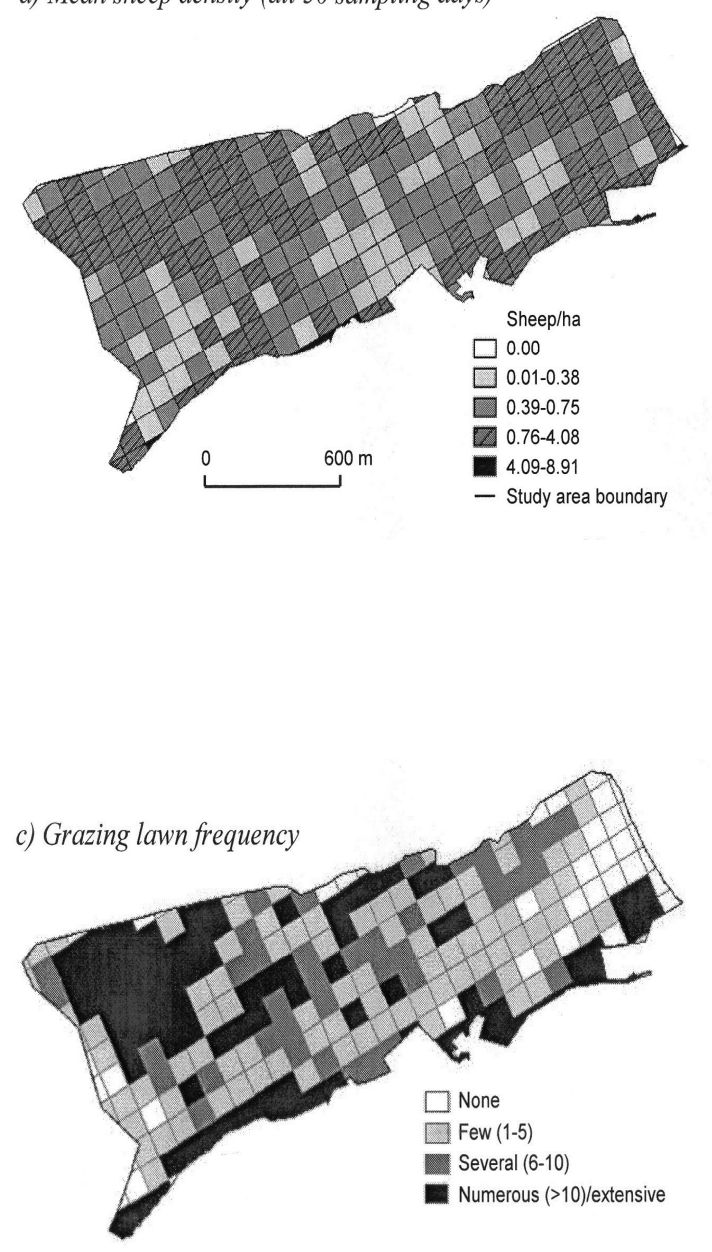

b) Habitats
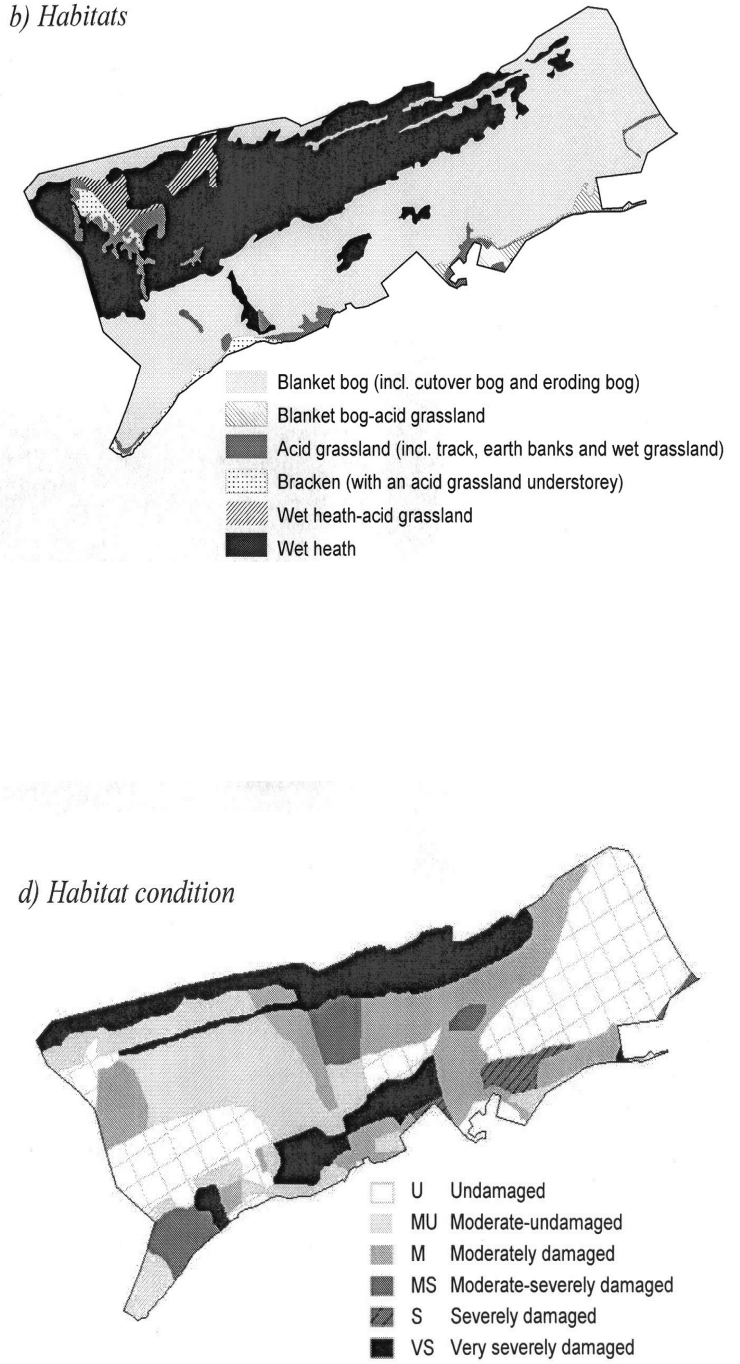

Figure 3. Spatial distribution maps of sheep occupation, habitats, grazing lawn frequencies and habitat conditions for the study area. 
a) Sampling day no. 8 of 10, autumn 2004

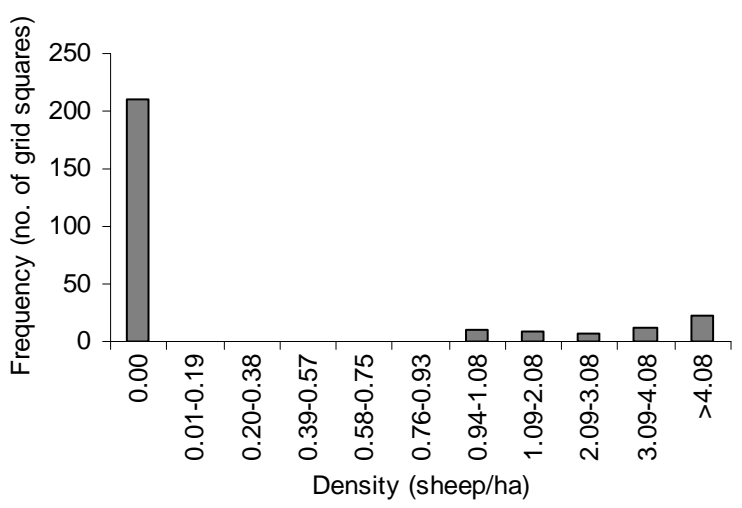

b) Sampling day no. 4 of 10, summer 2005

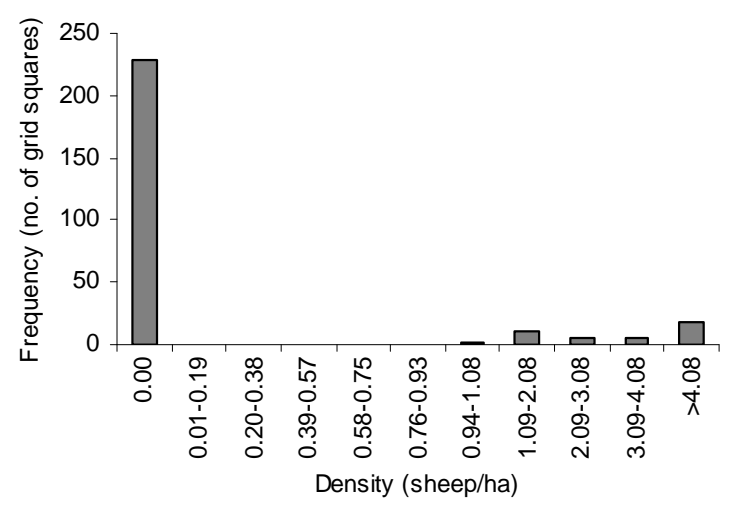

Figure 4. Sheep densities observed in the study area which consisted of 270 grid squares. These are typical frequency histograms from two randomly-selected sampling days.

Data presented in sub-sections are based solely on direct flock observations.

\section{Habitat selection}

Eleven polygon habitats were available to grazers (Table 1a). The dominant habitats were blanket bog and wet heath, which combined accounted for $88.1 \%$ of the study area (Table 1a, Fig. 3b). Wet heath was mostly associated with the slopes of the northern half of the study area and blanket bog with the more level areas, typically at lower altitudes. 
Table 2. Tests for random use of habitats by Scottish Blackface hill sheep based on direct observations. The habitat ranking is shown in parentheses when $\Lambda$ is not significant and '>>>' denotes a significant difference between two consecutively ranked habitats.

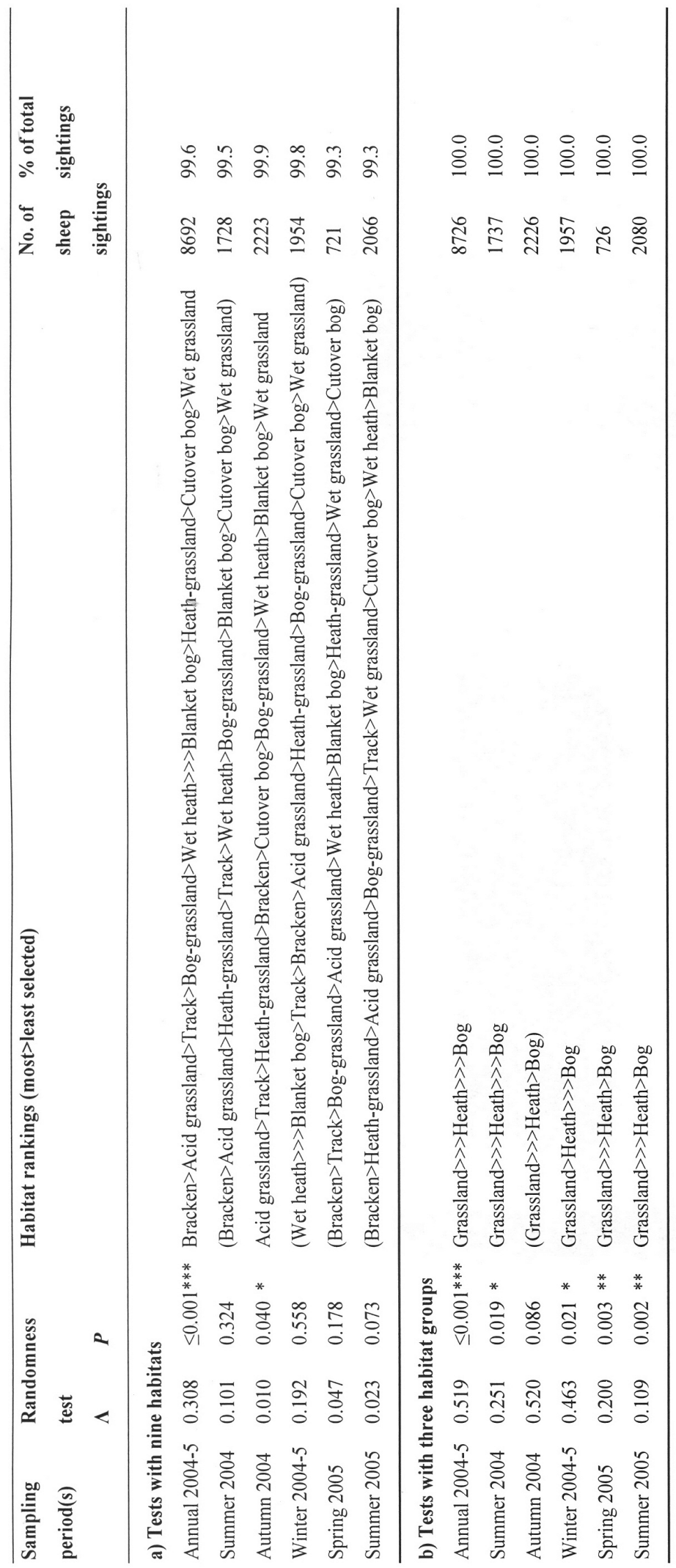

APPLIED ECOLOGY AND ENVIRONMENTAL RESEARCH 8(4): 279-299. http://www.ecology.uni-corvinus.hu • ISSN 15891623 (Print) • ISSN 17850037 (Online) (c) 2010, ALÖKI Kft., Budapest, Hungary 
Habitat selection tests (Table 2a) were conducted with only nine of the 11 polygon habitats because earth banks and eroding bog had to be omitted since too many zero values, indicative of low use, prohibited analyses running. Habitat selection by sheep was only significant $(P<0.05)$ for autumn and annual tests, although habitat ranks were still considered to be meaningful (Williams, 2008). Bracken (Pteridium aquilinum L. Kuhn) was selected most in both summers and spring, and acid grassland was selected most in autumn. Wet heath followed by blanket bog were most selected in winter whereas these two habitats were of intermediate to low rank in the other seasons. No two rank sequences were identical, indicating variation between seasons and years.

To include all polygon habitat data and to simplify comparison with results previously obtained from GPS tracking of ewes (section 3.5), the 11 habitats were combined into three groups (Table $1 a$ ) and tests re-run. Habitat group selection was significant $(P<0.05)$ for all tests except autumn (Table $2 b)$. The selection rank for all tests was consistently acid grassland-related habitats selected most, followed by wet heath, and blanket bog habitats selected least.

\section{Grazing lawn frequency selection}

Grid squares containing few (36.8\%) and numerous/extensive $(34.3 \%)$ grazing lawns were the most frequently occurring (Table $1 b$ ). The largest block of grid squares containing numerous/extensive grazing lawns was found in the northwest corner of the study area, some were also located along the southern boundary and scattered elsewhere (Fig. 3c).

Selection of grid squares containing different frequencies of grazing lawns was significant $(\mathrm{P}<0.05)$ annually and for all seasons except winter (Table 3). All four categories were suitable for analysis and did not lend themselves to further grouping as with habitat selection analyses. Grid squares containing numerous/extensive grazing lawns were selected most overall and in all seasons tested. The rank of the subsequent three categories varied slightly between seasons and years.

Table 3. Tests for random use, by Scottish Blackface hill sheep, of grid squares consisting of varying grazing lawn frequencies (based on direct observations). The grazing lawn frequency ranking is shown in parentheses when $\Lambda$ is not significant and '>>>' denotes a significant difference between two consecutively ranked frequency categories.

\begin{tabular}{lllllll}
\hline $\begin{array}{l}\text { Sampling } \\
\text { period(s) }\end{array}$ & \multicolumn{2}{l}{ Randomness test } & \multicolumn{2}{l}{$\begin{array}{l}\text { Grazing lawn frequency rankings } \\
\text { (most>least selected) }\end{array}$} & $\begin{array}{l}\text { No. of } \\
\text { sightings }\end{array}$ & $\begin{array}{c}\text { \% of total } \\
\text { sightings }\end{array}$ \\
\hline Annual 2004-5 & 0.459 & $\leq 0.001 * * *$ & Numerous $>>$ Several $>$ None>Few & 8726 & 100.0 \\
Summer 2004 & 0.135 & $0.008 * *$ & Numerous $>$ None $>$ Several $>$ Few & 1737 & 100.0 \\
Autumn 2004 & 0.304 & $0.035 *$ & Numerous $>$ None $>$ Several $>$ Few & 2226 & 100.0 \\
Winter 2004-5 & 0.908 & 0.877 & (Numerous $>$ None $>$ Several $>$ Few) & 1957 & 100.0 \\
Spring 2005 & 0.144 & $0.013 *$ & Numerous $>>$ Several $>>$ Few $>$ None & 726 & 100.0 \\
Summer 2005 & 0.069 & $0.002 * *$ & Numerous $>>$ Several $>$ None $>$ Few & 2080 & 100.0 \\
\hline
\end{tabular}




\section{Habitat condition selection}

All condition categories from undamaged to very severely damaged areas occurred in the study area (Table 1c). The most dominant single category available was undamaged areas $(29.5 \%)$. Moderately damaged categories combined accounted for $48.8 \%$ of the study area and severely damaged categories combined accounted for $21.8 \%$. A mosaic of habitat conditions was found (Fig. 3d). Severely damaged areas were most associated with the mountain ridge and, in places, at low altitudes. Moderate damage was mostly associated with the northern half of the study area and undamaged areas were mostly associated with more level areas at low altitude.

Selection of areas with varying habitat condition, using all six categories, was significant $(P<0.05)$ annually and for all seasons except winter (Table 4a). Moderateundamaged areas were selected most in both summers, autumn, spring and annually but second-least in winter when moderately damaged areas were selected most. Severely damaged areas were selected least in all tests except second-least in summer 2005. Very severely damaged areas had a low selection rank of five out of six in autumn, rose to four in spring, and were selected more in summer of both years and spring with a selection rank of three.

Table 4. Tests for random use of habitat condition categories by Scottish Blackface hill sheep based on direct observations. The habitat condition ranking is shown in parentheses when $\Lambda$ is not significant and '>>>' denotes a significant difference between two consecutively ranked condition categories.

\begin{tabular}{llllll}
\hline $\begin{array}{l}\text { Sampling } \\
\text { period(s) }\end{array}$ & \multicolumn{1}{c}{ Randomness test } & $\boldsymbol{P}$ & $\begin{array}{l}\text { Habitat condition rankings } \\
(\text { most }>\text { least selected) }\end{array}$ & $\begin{array}{l}\text { No. of } \\
\text { sightings }\end{array}$ & $\begin{array}{l}\text { \% of total } \\
\text { sightings }\end{array}$ \\
\hline a) Tests with six condition categories & & \\
Annual 2004-5 & 0.446 & $\leq 0.001^{* * *}$ & MU $>\mathrm{M}>\mathrm{U}>>>\mathrm{VS}>\mathrm{MS}>>>\mathrm{S}$ & 8726 & 100.0 \\
Summer 2004 & 0.169 & $0.036 *$ & $\mathrm{MU}>>>\mathrm{M}>\mathrm{VS}>\mathrm{U}>\mathrm{MS}>\mathrm{S}$ & 1737 & 100.0 \\
Autumn 2004 & 0.036 & $\leq 0.001^{* * *}$ & $\mathrm{MU}>\mathrm{U}>\mathrm{M}>\mathrm{MS}>\mathrm{VS}>\mathrm{S}$ & 2226 & 100.0 \\
Winter 2004-5 & 0.154 & 0.053 & $(\mathrm{M}>\mathrm{U}>\mathrm{VS}>\mathrm{MS}>\mathrm{MU}>\mathrm{S})$ & 1957 & 100.0 \\
Spring 2005 & 0.085 & $0.011 *$ & $\mathrm{MU}>>>\mathrm{M}>\mathrm{U}>\mathrm{VS}>\mathrm{MS}>\mathrm{S}$ & 726 & 100.0 \\
Summer 2005 & 0.134 & $0.039 *$ & $\mathrm{MU}>\mathrm{M}>\mathrm{VS}>\mathrm{U}>\mathrm{S}>\mathrm{MS}$ & 2080 & 100.0 \\
\hline b) Tests with three condition groups & & & \\
Annual 2004-5 & 0.341 & $\leq 0.001 * * *$ & $\mathrm{M}>>>\mathrm{U}>>>\mathrm{S}$ & 8726 & 100.0 \\
Summer 2004 & 0.710 & 0.223 & $(\mathrm{M}>\mathrm{S}>\mathrm{U})$ & 1737 & 100.0 \\
Autumn 2004 & 0.047 & $0.003 * *$ & $\mathrm{M}>\mathrm{U}>>>\mathrm{S}$ & 2226 & 100.0 \\
Winter 2004-5 & 0.365 & $0.017 *$ & $\mathrm{M}>\mathrm{U}>\mathrm{S}$ & 1957 & 100.0 \\
Spring 2005 & 0.218 & $0.006 * *$ & $\mathrm{M}>>>\mathrm{U}>>>\mathrm{S}$ & 726 & 100.0 \\
Summer 2005 & 0.444 & $0.040 *$ & $\mathrm{M}>>>\mathrm{S}>\mathrm{U}$ & 2080 & 100.0
\end{tabular}

${ }^{\mathrm{a}} \mathrm{U}=$ undamaged, $\mathrm{MU}=$ moderate-undamaged, $\mathrm{M}=$ moderately damaged, $\mathrm{MS}=$ moderate-severely damaged, $\mathrm{S}$ = severely damaged, VS = very severely damaged areas. 
The six condition categories were grouped into the three broader categories (Table 1c) defined by Dúchas the Heritage Service and the Department of Agriculture and Food (1999) and selection tests were re-run. Selection was significant $(P<0.05)$ annually and for all sampling periods except summer 2004 (Table 4b). Moderately damaged areas were consistently selected most in all tests. Severely damaged areas were selected least annually and in autumn, winter and spring, whereas severely damaged areas were second-most selected in both summers.

While visual comparison of the four maps presented in Figure 3 suggests there is not a clear, direct link between flock distribution, habitats, grazing lawn frequencies and/or habitat condition, in summary, compositional analysis results suggest that flock distribution was generally associated with acid grassland, numerous/extensive grazing lawns and moderately damaged areas.

\section{Direct flock observations and GPS tracking results compared}

Habitat rank sequences with three habitat groups based on direct flock observations matched those based on GPS data for all seasons at the detailed selection level and for summer and autumn at the broad level. When comparing flock observations with GPS data at the broad level with five habitats common to both sets of tests, there were similarities and differences. Examples of similarities include wet heath being selected most in winter and acid grassland selected most in autumn with blanket bog least, preceded by wet heath in both sets of results. Examples of inconsistencies in results between methods include blanket bog selected second-most in winter with flock observations but least with GPS data, and bracken selected most in spring with flock observations but second-least with GPS data.

Grid squares containing numerous/extensive grazing lawns were most selected in all tests, i.e. in all seasons and at all selection levels, based on direct flock observations and GPS tracking data (Williams et al., 2009).

Moderately damaged areas were consistently selected most in tests using flock observation data and GPS data (Williams et al., 2009). Both methods indicated a higher selection of severely damaged areas in summer (results from GPS data presented in (Williams et al., 2009), although this was also found to be true in spring using flock observation data.

\section{Discussion}

\section{Direct flock observations}

The majority of the flock was sighted when following the chosen route. Complex topography with hummocks, hollows and steep slopes obscured some sheep from view and hindered observer access to some areas. Visibility did not affect proportions of the flock sighted.

Grazing was the main behaviour activity observed and more so in winter than other seasons, which is consistent with findings by others. Scottish Blackface sheep are reported to graze hill vegetation $79 \%$ of daylight time in winter (Hulbert et al., 1998), $53 \%$ in summer (Clarke et al., 1995) and 60\% in summer and autumn (Hester et al., 1999). Proportions of sightings are probably indicative of time spent on respective behaviour activities and values for summer and autumn are similar to those of (Hester et al., 1999). Feeding blocks were available in the trial by (Hulbert et al., 1998) which may 
explain the lower proportion of time spent grazing in winter compared with observations in this study where no supplementary feed was available.

Uneven sheep distribution and a preference for the northwest quarter of the study area are consistent with findings from GPS data (Williams, 2008) and are likely to be explained by resource selection as discussed below. Hill sheep, including Scottish Blackface, are thought to learn home ranges from their dams and are known to return to the same areas (Hunter and Milner, 1963; Lawrence and Wood-Gush, 1988). Foraging behaviour is also reported to be influenced by experiences of individuals (Provenza and Cincotta, 1993). Therefore, a feedback loop probably occurs between experience gained of environmental conditions, including habitats, grazing lawns and habitat condition, and home ranges subsequently passed on to offspring/learned. High occupation of the northwest quarter of the study area is consistent with findings that hill sheep prefer the area with the highest elevation (Berggren-Thomas and Hohenboken, 1986).

A striking finding is that sheep densities ranged between 0.00 and 158.13 sheep/ha (0.00-8.91 mean over 50 sampling days). Many studies of hill sheep behaviour are plotbased trials which provide valuable information but cannot explore sheep densities applicable to open hill situations. Conversely, Lawrence and Wood-Gush (1988) studied sheep behaviour on an open hill area but did not report on sheep densities. Hewson and Wilson (1979) reported a maximum of 35 sheep and 14 lambs on a heavily grazed coastal grassland area about 1.6 ha in size (equivalent to 30.6 sheep/ha). A comparison between Hewson and Wilson's study and the present study would be unfair because different methods were used, including the use of a 1 ha grid and more advanced technology (i.e. GIS software) in this study. Occasional highs of 16 sheep in 0.1 ha (equivalent to 158.1 sheep/ha but strongly influenced by grid positioning) and 23 sheep in complete, 1 ha grid squares (i.e. equivalent to 23.0 sheep/ha) were observed in this study. This information highlights the level of selection that can be exhibited by hill sheep on heterogeneous upland topography and associated vegetation.

The highest observed sheep density (158.13 sheep/ha) occurred in mid-October 2004 when the weather was dry, windy and overcast with high visibility. Sixteen sheep were observed occupying a grid square which was on the mid-northern boundary and only 0.10 ha in size, estimated using ArcGIS. The grid square was on the mountain ridge, with steep slopes and rock outcrops indicative of shallower soils than elsewhere, and dominated by wet heath.

\section{Habitat selection}

In tests with nine habitats, bracken was most selected in both summers and spring, probably because it supported an understorey of acid grassland, and acid grassland was selected most in autumn. Acid grassland-related habitats were consistently selected most in tests with three habitat groups. Preference for grassland on heterogeneous hill vegetation is consistent with findings by others (Welch, 1984; Clarke et al., 1995; Hester et al., 1999). Probable explanations for a preference of acid grassland include high vegetation productivity potential (McNaughton, 1984), higher protein and energy concentration and plant biomass (Doyle, 1979, Doyle, 1982) and higher digestibility and herbage intake on acid grassland than heath or blanket bog (Hodgson et al., 1991).

Seasonal variation in habitat rankings based on nine habitats is probably explained by seasonal variation reported in plant palatability and hill sheep diets (Bullock, 1985, Grant et al., 1987). For example, acid grassland patches in the study area are dominated by Molinia caerulea (L.) Moench (O'Dowd, 2005) which dies back in early autumn and 
this provides a likely explanation for the top selection rank of wet heath as opposed to acid grassland in winter. When habitats were grouped, the broad selection trends were found but detail at habitat level was lost which is probably why heath was second to grassland-related habitats in winter for this test. This highlights the importance of conducting analyses with separate habitats (and ensuring sample sizes are large enough to do so) in addition to habitat groups because wet heath and blanket bog habitats were most selected in winter, which has important management implications.

Blanket bog-related habitats were consistently selected least, or most 'avoided', in tests based on the three habitat groups. Likely explanations include low vegetation productivity, digestibility and herbage intake, and a deficiency in minerals (Hodgson et al., 1991), combined with taller vegetation which sheep find more difficult to graze (Grant et al., 1985). Additionally, features associated with this habitat that made it difficult for sheep to move through, included bog pools, surface water, drainage ditches and areas of quaking peat.

Minor variation in habitat selection rank sequences between tests based on direct flock observations and GPS tracking data may be explained by flock observation analyses being intermediate between broad and detailed selection levels tested with GPS data. However, trends were generally consistent and led to the same conclusions.

\section{Grazing lawn frequency selection}

Grid squares containing numerous/extensive grazing lawns were associated with a large bowl-like feature and adjacent hillock in the northwest corner, the riverbank on the western half of the southern boundary, farm tracks and earth banks along the eastern half of the southern boundary, and scattered hillocks, rock outcrops and/or sloping ground with well-drained soils. Absence of grazing lawns was typically associated with areas of waterlogged, deep, quaking peat on relatively level ground, and occasionally with very steep north-facing slopes inaccessible to sheep on the northern boundary. The distribution of grazing lawns is probably explained by sheep being reported to congregate and produce grazing lawns where vegetation productivity potential is high and to disperse from areas where potential is low (McNaughton, 1984).

Sheep most selected grid squares containing numerous/extensive grazing lawns in all seasons, which is consistent with findings based on GPS data (Williams et al., 2009). A close association between flock and grazing lawn distribution was expected as grazing lawns are a product of intensive grazing. During the plant growing season, selection is probably explained by the relatively better forage quality and availability of acid grassland as discussed above. Selection for grid squares containing numerous/extensive grazing lawns outside the vegetation growing season, when forage quality of acid grassland is relatively lower, is probably explained by sheep known to return to learned home ranges and to concentrate grazing activity in close proximity to grassland patches rather than further away (Clarke et al., 1995; Hester and Baillie, 1998). Additionally, grid squares typically supported and were often dominated by alternative habitats such as wet heath.

\section{Habitat condition selection}

Severely damaged areas were most associated with the mountain ridge, which is probably largely explained by wind-driven rain and its effect on soil erosion reported to be most severe close to the top of a hill (Choi, 2002). Severely damaged areas on the 
southern boundary at low altitude were associated with deep peat, relatively level ground, waterlogging most of the year, former peat extraction in places and poaching on routes used when sheep were gathered and released from the yard. Moderately damaged areas were mostly associated with steeper slopes dominated by wet heath where sheep paths traversed the hill. Undamaged areas were species poor, dominated by tall, rank purple moor-grass and were arguably undergrazed.

Grazers can facilitate damage to upland habitats, conversely, they increase diversity in plant species composition, height and structure and the fauna this supports (Rowell and Clarke, 1988). While increasing diversity has benefits, creation of acid grassland patches is at the expense of wet heath (van Eck et al., 1984; Gillmor and Walsh, 1993; Thompson et al., 1995b) which, unlike acid grassland, is listed under Annex I of the Habitats Directive. Some acid grassland patches are inevitable where livestock graze hill vegetation and the spread of grassland patches is likely (Clarke et al., 1995).

Moderately damaged areas were selected most, which was consistent with GPS data. Relatively better forage quality associated with these areas, compared with severely damaged areas that support higher proportions of exposed soil and undamaged areas that support tall vegetation that is difficult to graze, provides a probable explanation.

Higher selection of severely damaged areas in summer is consistent with findings from GPS data (Williams et al., 2009), although this study also found this to be true in spring. Use of severely damaged areas particularly during the vegetation growing season raises concerns as grazing-related pressure is likely to inhibit recovery in areas where the proportion of exposed peat is highest. Seasonal selective grazing for preferred species probably explains use of these areas as Scottish Blackface sheep are thought to be more selective in summer when environmental heterogeneity is highest (Lawrence and Wood-Gush, 1988). Eriophorum spp. (L.) and Narthecium ossifragum (L.) Huds) were abundant species on areas of exposed peat and (Grant et al., 1987) reported high proportions of these in the diets of Scottish Blackface sheep grazing blanket bog during the plant growing season.

\section{Implications for conservation}

An important finding from this study based on direct flock observations was that habitat, grazing lawn frequency and habitat condition selection trends matched those previously obtained from thousands of GPS tracking data for only a small number of individuals. This adds credence to findings from these two, very different research methods, indicating that both methods produced results that are likely to be representative of the flock. Additionally, it reinforces management recommendations previously made (including by Williams (2008) and Williams et al. (2009)). These recommendations were that; (i) stocking rate calculations should be based on grazer behaviour, relative proportions of habitats available and habitat condition, (ii) areas of habitats selected least (i.e. avoided; blanket bog habitats in this study) should be omitted from stocking rate calculations, (iii) additional measures, such as fencing, are probably also necessary to meet conservation objectives, (iv) stocking rates should not increase the number or extent of acid grassland patches at the expense of heathland, (v) grazing lawn frequency mapping could be used as an indicator of grazer distribution and subsequent grazer impact predictions, and (vi) additional information on grazer selection should be gathered and incorporated into hill management models such as HillPlan (Macaulay Institute, 2009) and used to aid decision-making. 
Flock distribution ranged between grid squares that were unvisited and where very high stocking densities were observed on occasion. Uneven grazing pressure combined with all six habitat conditions occurring in the one study area, which was managed as a single unit, makes management planning problematic. Areas with different condition categories and carrying capacities require different management prescriptions but compartmentalising an upland/open hill site, e.g. using fencing, is labour intensive and expensive, neither of which are conducive to the hill sheep enterprise with high dependence on off-farm employment and low profit margins (Connolly et al., 2007). Exclusion of grazers from targeted areas and sheep numbers calculated based on habitat availability, grazer selection and habitat condition, should facilitate vegetation recovery on exposed peat and reduce grazer impact on damaged areas. In this and similar instances, grazers should be excluded from extensive severely damaged areas, e.g. the area associated with the mountain ridge, and effects monitored. Gathering sheep is an essential practice for production and animal welfare and routes that cross blanket bog were unavoidable, therefore use of erosion control mats or other ground reinforcement technology to withstand and contain trampling pressure on localised eroded patches could be considered.

Seasonal selection rankings of habitats, grazing lawns and habitat conditions provide useful information that could be used to predict foraging behaviour and consequently grazer impact on vegetation. Seasonal grazing regimes should be devised that meet habitat conservation objectives at site-level based on grazer behaviour and habitat condition. Traditionally, hill sheep overwintered in paddocks on the lower hills in Wales (Cunningham, 1979). Habitats with higher conservation importance and lower carrying capacities were most selected in winter, therefore, it is recommended that grazers are removed from areas of semi-natural hill vegetation during this period. On sites where fields of improved agricultural grassland are unavailable, creation of such areas could be considered to provide conservation support areas to the majority of the upland and peatland contained. Typically hill sites in western Ireland that do not already have fields of improved grassland are unlikely to have suitable sites for either improved grassland or livestock housing, in which case selling sheep at the start of winter and buying replacements in spring may be the only feasible option if conservation objectives are to be met.

Recommendations made above should not compromise the financial viability of hill farming, i.e. if extra costs are involved, farmers should be compensated accordingly. This enterprise is highly dependent on agri-environment payments which should continue to pay farmers to manage land for conservation but with revised management agreements, increasing the efficacy of agri-environment schemes in this sector based on new findings on grazer behaviour. Further studies are required on multiple study sites, with varying topography and vegetation assemblages, to obtain sufficient data on resource selection by hill sheep for inclusion as parameters in management models. Although this study investigated hill sheep selection on a mosaic of upland and peatland habitats, the same applications could be made to aid conservation decision-making on a wide variety of assemblages of habitats, plant communities and vegetation condition, and with a range of study animals. 
Acknowledgements: Thanks to Teagasc for funding this research under the Walsh Fellowship Scheme, and the following for their assistance; Luke O'Malley, PJ Hastings, J.P. Hanrahan, Juan Carlos Castaneda, Rod Green, John Warren, James Moran, John Connolly, Stephen Kelly, Andy Bleasdale and Peter Smith.

\section{REFERENCES}

[1] Aebischer, N.J., Robertson, P.A., Kenward, R.E. (1993): Compositional analysis of habitat use from animal radio-tracking data. - Ecology 74: 1313-1325.

[2] Armstrong, H.M., Gordon, I.J., Grant, S.A., Hutchings, N.J., Milne, J.A., Sibbald, A.R. (1997a): A model of the grazing of hill vegetation by sheep in the UK. I. The prediction of vegetation biomass. - Journal of Applied Ecology 34: 166-185.

[3] Armstrong, H.M., Gordon, I.J., Hutchings, N.J., Illius, A.W., Milne, J.A., Sibbald, A.R. (1997b): A model of the grazing of hill vegetation by sheep in the UK. II. The prediction of offtake by sheep. - Journal of Applied Ecology 34: 186-207.

[4] Berggren-Thomas, B., Hohenboken, W.D. (1986): The effects of sire-breed, forage availability and weather on the grazing behavior of crossbred ewes. - Applied Animal Behaviour Science 15: 217-228.

[5] Bleasdale, A., Heffron, J. (1999): A Vegetation Condition Assessment of the Teagasc Hill Sheep Farm, Erriff, Co. Mayo. Dúchas and Department of Agriculture and Food, Dublin.

[6] Bullock, D.J. (1985): Annual diets of hill sheep and feral goats in southern Scotland. Journal of Applied Ecology 22: 423-433.

[7] Cadbury, C.J. (1987): Moorland birds - Britain's international responsibility. - In: Cadbury, C.J., Everett, M. (eds.) RSPB Conservation Review 1987, Royal Society for the Protection of Birds, Sandy.

[8] Choi, E.C.C. (2002): Modelling of wind-driven rain and its soil detachment effect on hill slopes. - Journal of Wind Engineering and Industrial Aerodynamics 90: 1081-1097.

[9] Clarke, J.L., Welch, D., Gordon, I.J. (1995): The influence of vegetation pattern on the grazing of heather moorland by red deer and sheep. I. The location of animals on grass/heather mosaics. - Journal of Applied Ecology 32: 166-176.

[10] Connolly, L., Kinsella, A., Quinlan, G., Moran, B. (2007): National Farm Survey 2006. www.teagasc.ie/publications/2007/20070730/NationalFarmSurvey2006.pdf [Last accessed January 2010].

[11] Cunningham, J.M.M. (1979): Chapter 1: A perspective of twenty-five years of hill farming research. - In: Board of Management HFRO (ed.) Science and Hill Farming: Twenty-five years of work at the Hill Farming Research Organisation 1954-1979, Hill Farming Research Organisation.

[12] Department of Arts Heritage Gaeltacht and the Islands (2002): National Biodiversity Plan. - Government of Ireland, Dublin.

[13] Doyle, G.J. (1982): The vegetation, ecology and productivity of Atlantic blanket bog in Mayo and Galway, western Ireland. - Journal of Life Sciences Royal Dublin Society 3: 147-164.

[14] Doyle, J.J. (1979): The effect of nitrogen, phosphorus and potassium fertilization on chemical content of sheep diets. - Journal of Range Management 32: 162-163.

[15] Dúchas the Heritage Service, the Department of Agriculture and Food (1999): A Manual for the Production of Grazing Impact Assessments in Upland and Peatland Habitats. Dúchas the Heritage Service \& the Department of Agriculture and Food, Dublin.

[16] Dýrmundsson, Ó.R. (2006): Sustainability of sheep and goat production in North European countries: from the Arctic to the Alps. - Small Ruminant Research 62: 151157. 
[17] European Commission (2008): EU Nature Legislation.

$<$ http://ec.europa.eu/environment/nature/legislation/index_en.htm> [Last accessed January 2010].

[18] European Environmental Advisory Councils (1999): Annex: Agriculture and environment in eight European countries. <http://www.eeac-

net.org/workgroups/pdf/WGAgriculture_Agenda200_Proposals_1999_Annex.pdf> [Last accessed January 2010].

[19] Fossitt, J.A. (2000): A Guide to Habitats in Ireland. - The Heritage Council, Kilkenny.

[20] Gardiner, M.J., Radford, T. (1980): Soil Associations of Ireland and their Land Use Potential. Soil Survey Bulletin No. 36 -An Foras Talúntais, Dublin.

[21] Gillmor, D.A., Walsh, J.A. (1993): County-level variations in agricultural adjustment in Ireland in the 1980s. - Geographical Viewpoint 21: 25-44.

[22] Grant, S.A., Suckling, D.E., Smith, H.K., Torvell, L., Forbes, T.D.A., Hodgson, J. (1985): Comparative studies of diet selection by sheep and cattle: the hill grasslands. - Journal of Ecology 73: 987-1004.

[23] Grant, S.A., Torvell, L., Smith, H.K., Suckling, D.E., Forbes, T.D.A., Hodgson, J. (1987): Comparative studies of diet selection by sheep and cattle: blanket bog and heather moor. - Journal of Ecology 75: 947-960.

[24] Heady, H.F. (1964): Palatability of herbage and animal preference. - Journal of Range Management 17: 76-82.

[25] Heritage Council (2002): Habitat Survey Guidelines: A Standard Methodology for Habitat Survey and Mapping in Ireland - Draft. - The Heritage Council [Source: Liam Lysaght pers. comm. email: liam@heritagecouncil.com], Kilkenny.

[26] Hester, A.J., Baillie, G.J. (1998): Spatial and temporal patterns of heather use by sheep and red deer within natural heather/grass mosaics. - Journal of Applied Ecology 35: 772784.

[27] Hester, A.J., Gordon, I.J., Baillie, G.J., Tappin, E. (1999): Foraging behaviour of sheep and red deer within natural heather/grass mosaics. - Journal of Applied Ecology 36: 133146.

[28] Hewson, R., Wilson, C.J. (1979): Home range and movements of Scottish Blackface sheep in Lochaber, north-west Scotland. - Journal of Applied Ecology 16: 743-751.

[29] Hodgson, J., Forbes, T.D.A., Armstrong, R.H., Beattie, M.M., Hunter, E.A. (1991): Comparative studies of the ingestive behaviour and herbage intake of sheep and cattle grazing indigenous hill plant communities. - Journal of Applied Ecology 28: 205-227.

[30] Hulbert, I.A.R., Wyllie, J.T.B., Waterhouse, A., French, J., McNulty, D. (1998): A note on the circadian rhythm and feeding behaviour of sheep fitted with a lightweight GPS collar. - Applied Animal Behaviour Science 60: 359-364.

[31] Hunter, R.F. (1962): Hill sheep and their pasture: a study of sheep-grazing in south-east Scotland. - Journal of Ecology 50: 651-680.

[32] Hunter, R.F., Milner, C. (1963): The behaviour of individual, related and groups of south country Cheviot hill sheep. - Animal Behaviour 11: 507-513.

[33] Iason, G.R., Mantecon, A.R., Sim, D.A., Gonzalez, J., Foreman, E., Bermudez, F.F., Elston, D.A. (1999): Can grazing sheep compensate for a daily foraging time constraint? - Journal of Animal Ecology 68: 87-93.

[34] Johnson, D.H. (1980): The comparison of usage and availability measurements for evaluating resource preference. - Ecology 61: 65-71.

[35] Lawrence, A.B., Wood-Gush, D.G.M. (1988): Home-range behaviour and social organization of Scottish Blackface sheep. - Journal of Applied Ecology 25: 25-40.

[36] Macaulay Institute (2009): Decision support tools to link ecology and land management: Development of HillPlan. <www.macaulay.ac.uk/hillplan/> [Last accessed January 2010].

[37] McInnis, M.L., Vavra, M., Krueger, W.C. (1983): A comparison of four methods used to determine the diets of large herbivores. - Journal of Range Management 36: 302-306. 
[38] McNaughton, S.J. (1984): Grazing lawns: animals in herds, plant form, and coevolution. - American Naturalist 124: 863-886.

[39] Met Éireann (undated): Climate of Ireland. <www.met.ie/climate/climate-of-ireland.asp> [Last accessed January 2010].

[40] Moravec, J., Zemeckis, R. (2007): Cross Compliance and Land Abandonment. Institute for European Environmental Policy, Brussels.

[41] Nature Conservancy Council (1990): Handbook for Phase 1 Habitat Survey: a Technique for Environmental Audit. - Joint Nature Conservation Committee, UK.

[42] O'Dowd, D. (2005): A study of the vegetation of sheep rests at Teagasc Hill Sheep farm, Leenaun, with particular reference to Nardus stricta. - Unpublished BSc Thesis, National University of Ireland, Galway.

[43] Provenza, F.D., Cincotta, R.P. (1993): Chapter 5: Foraging as a self-organizational learning process: accepting adaptability at the expense of predictability. - In: Hughes, R.N. (ed.) Diet Selection: An Interdisciplinary Approach to Foraging Behaviour, Blackwell Scientific Publications, Oxford.

[44] Rowell, T.A., Clarke, M.J. (1988): Grazing. - In: Rowell, T.A. (ed.) The Peatland Management Handbook: Research and Survey in Nature Conservation No. 14, Nature Conservancy Council, Peterborough.

[45] Sibbald, A.M., Shellard, L.J.F., Smart, T.S. (2000): Effects of space allowance on the grazing behaviour and spacing of sheep. - Applied Animal Behaviour Science 70: 49-62.

[46] Thompson, D.B.A., MacDonald, A.J., Hudson, P.J. (1995a): Chapter 11: Upland Moors and Heaths. - In: Sutherland, W.J., Hill, D.A. (eds.) Managing Habitats for Conservation, Cambridge University Press, Cambridge.

[47] Thompson, D.B.A., MacDonald, A.J., Marsden, J.H., Galbraith, C.A. (1995b): Upland heather moorland in Great Britain: a review of international importance, vegetation change and some objectives for nature conservation. - Biological Conservation 71: 163178.

[48] Umstätter, C., Waterhouse, A., Holland, J.P. (2008): An automated sensor-based method of simple behavioural classification of sheep in extensive systems. - Computers and Electronics in Agriculture 64: 19-26.

[49] van Eck, H., Govers, A., Lemaire, A., Schaminée (1984): Irish Bogs: a Case for Planning. - Katholieke Universiteit, Nijmegen.

[50] Walsh, M., Mulqueen, J., Grennan, E., Rogers, M., Marren, N., Guinan, L., Nixon, D., Collins, J.F. (2000): Evaluation of the Impact of Livestock on the Hill Environment. End of Project Reports: Sheep Series No. 10. Project No. 4043. - Teagasc Agriculture and Food Development Authority, Sheep Research Centre, Athenry.

[51] Welch, D. (1984): Studies in the grazing of heather moorland in north-east Scotland. I. Site descriptions and patterns of utilization. - Journal of Applied Ecology 21: 179-195.

[52] Williams, B. (2008): Resource selection by Scottish Blackface sheep on a mosaic of upland and peatland habitats: implications for conservation management. - Unpublished $\mathrm{PhD}$ thesis, National University of Ireland, Galway.

[53] Williams, B., Walls, S., Walsh, M., Gormally, M., Bleasdale, A. (2009): Proposing an efficient indicator of grazer distribution on heterogeneous hill vegetation. - Applied Ecology and Environmental Research 7: 341-358.

[54] Williams, O.B. (1969): An improved technique for identification of plant fragments in herbivore feces. - Journal of Range Management 22: 51-52. 